\title{
Method for the Removal of Piumbum(II) Ion from Aqueous Solutions by Corn Cob as a Natural Adsorbent and from the View Point Thermodynamics
}

\author{
GHOLAMALI HAGHDOOST and HOSSEIN AGHAIE*
}

\author{
Department of Chemistry, Tehran Science and Research Branch, \\ Islamic Azad University, Tehran, Iran. \\ *Corresponding author E-mail: hn_aghaie@yahoo.com \\ http://dx.doi.org/10.13005/ojc/320322
}

(Received: May 30, 2016; Accepted: June 25, 2016)

\begin{abstract}
Corn cob as a low-cost adsorbent were used in the present work for the removal of toxic heavy metal $\mathrm{Pb}^{2+}$ from aqueous solutions. Bath experiments were used to determine the best adsorption conditions. The equilibrium adsorption level was determined as a function of solution $\mathrm{pH}$, temperature $(\mathrm{T})$, contact time(tc), initial adsorbate concentration, and adsorbent dosage. Effective removal of metal ions was demonstrated at $\mathrm{pH}$ values of 6 . Metal adsorption onto Corn cob was evaluated by Langmuir and Freundlich isotherms. Results indicate that the Langmuir isotherm model is the most suitable one for the adsorption process using Corn $\operatorname{cob}\left(R^{2}=0.9742\right)$, thus indicating the applicability of monolayer coverage of $\mathrm{Pb}$ (II) ion on Corn cob surface. The relationship between thermodynamic parameters was used to predict the absorption process. According to Thermodynamic analysis, the process endothermic and natural $\left(\Delta \mathrm{H}^{\circ}=-16.2 \mathrm{Jmol}^{-1}\right.$ and $\left.\Delta \mathrm{S}^{\circ}=-59.71 \mathrm{Jmol}^{-1} \mathrm{~K}^{-1}\right)$.
\end{abstract}

Keywords: Piumbum(II); adsorption;Thermodynamic;Corn cob.

\section{INTRODUCTION}

Rapid industrialization has led to increased disposal of heavy metals and radio nuclides into the environment. Lead and its compounds are toxic and present in wastewater, effluents and soils ${ }^{1}$. Lead is used in some batteries, metal plating, photographic materials, explosive manufacturing and in some other application ${ }^{2}$. The presence of lead compounds in water may damage the kidney, nervous system,
Liver, blood composition, reproductive system and brain due to its accumulation in the human body. Although individual metals exhibit specific signs of their toxicity, the following have been reported as general signs associated with cadmium, lead, arsenic, mercury, zinc, nickel, copper and aluminium poisoning: gastrointestinal (Gl) disorders, diarrhoea, stomatitis, tremor, heamoglobinuria causing a rust-red colour to stool, ataxia, paralysis, vomiting and convulsion, depression, and pneumonia when 
volatile vapours and fumes are inhaled ${ }^{3}$. Treatment processes for metal ions removal from wastewater include precipitation, reverse osmosis, Reduction, filtration, membrane processing, ion exchange, coagulation and adsorption process ${ }^{4}$. Adsorption technique has been developed as an efficient method for treating various wastewaters, in which activated carbons from natural resources have been used as efficient and economical adsorbents for removing heavy metal pollutants ${ }^{5}$. The use of activated carbons to remove $\mathrm{Pb}$ (II) from water was proposed because of their high surface areas and active functional groups leading to a search for low-cost adsorbents in recent years.

Indeed agricultural waste for example, has two advantages. First, waste material is converted to useful, value-added adsorbents. Disposal of agricultural by-products has become a major costly waste disposal problem. Second, produced activated carbons are used for removing organic chemicals and metals from wastewater ${ }^{6-9}$. Corn cob, flamboyant pods, apricot stone, almond shell, nut shell, peach stone, oat hulls, coconut husk, coconut shell, hazelnut shell, grape seed, olive stone and Rosa cantina sp. Seeds ${ }^{10-11}$ have been used for activated carbon production Ziziphus spina-christi is a plant that grows into a tree with thorny branches and is used as a hedge to form defensive fences for cattle. The

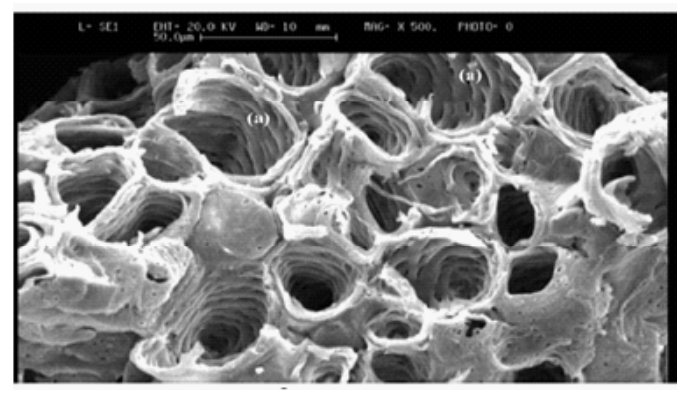

Fig. 1: SEM image of adsorbent of Corn cob before biosorption fruit has a sweet edible pulp, the leaves are applied locally to sores, and the roots are used to cure and prevent skin diseases ${ }^{12}$. Cedar with scientific name of Zizyphus spina christi grows in Saudi Arabia, north of Africa, and in Iran in provinces of Khuzestan, Fars, and Hormozgan. Such as: Iran. Jujube fruits are consumed fresh or processed into beverage and food. In the present study, Corn cobprepared used as an adsorbent to remove $\mathrm{Pb}$ (II) from aqueous solutions. The adsorption of $\mathrm{Pb}^{2+}$ ions onto Corn cob was studied in batch equilibrium conditions. The effects of different parameters including $\mathrm{pH}$, initial metal ion concentration, contact time, Corn cob dosage and temperature were investigated. Langmuir and Freundlich isotherm models were used to analyze the equilibrium data.

\section{EXPERIMENTAL}

\section{Apparatus and materials}

An AA 680 model atomic absorption spectrometer (Shimadzu Co.) was used for measuring the concentration of $\mathrm{Pb}^{2+}$ ion in studied solutions, a $820 \mathrm{~A}$ model $\mathrm{pH}$ meter (Metrohm Co.) was used to measure $\mathrm{pH}$ of solutions and a thermostatic orbit incubator shaker neolab model (India) was used to measure contact time in solution. All chemical materials used in this study were of analytical grade. Corn cob prepared by chemical activation with $\mathrm{KOH}$

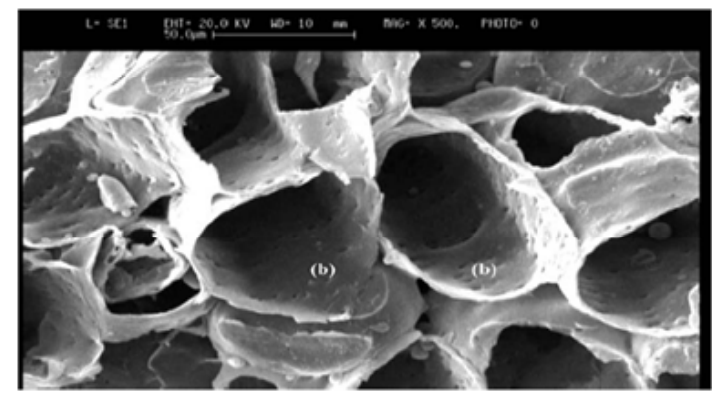

Fig. 2: SEM image of adsorbent of Corn cob after biosorption

Table 1: The effect of initial $\mathrm{pH}$ of the solution on the adsorption percentage $(\% A)$ of $\mathrm{Pb}^{2+}\left(\mathrm{C}_{\mathrm{o}}=10 \mathrm{mg} \cdot \mathrm{L}^{-1}, \mathrm{~W}_{\text {corn cob }}=50 \mathrm{mg}, \mathrm{T}=298 \mathrm{~K}, \mathrm{tc}=60 \mathrm{~min}\right)$

\begin{tabular}{cccccccc}
\hline $\mathbf{p H}$ & $\mathbf{4}$ & $\mathbf{5}$ & $\mathbf{6}$ & $\mathbf{7}$ & $\mathbf{8}$ & $\mathbf{9}$ & $\mathbf{1 0}$ \\
\hline$\% \mathrm{~A}$ & 59.2 & 64.5 & 75 & 73.2 & 71.4 & 68.5 & 65 \\
\hline
\end{tabular}


was characterized. Lead nitrate, was purchased from Merck Company.

\section{Batch adsorption experiments}

Batch adsorption experiments were carried out to determine the $\mathrm{Pb}^{2+}$ ions adsorption isotherm onto Corn cob and its thermodynamic properties. $\mathrm{Pb}^{2+}$ ions stock solution (100 mg. $\mathrm{L}^{-1}$ ) was prepared by dissolving the appropriate quantity of $\mathrm{Pb}\left(\mathrm{NO}_{3}\right)_{2}$ salt in deionized water.

Adsorption isotherms were obtained by using initial $\mathrm{Pb}^{2+}+$ ion concentration, $\mathrm{Co}$, and its

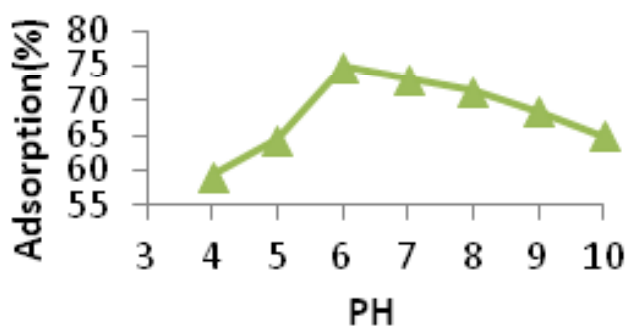

Fig. 3: The effect of initial pH of the solution on the adsorption percentage of $\mathrm{Pb}^{2+}\left(\mathrm{C}_{0}=10\right.$ $\mathrm{mg} \cdot \mathrm{L}^{-1}, \mathrm{~W}_{\text {Corn cob }}=50 \mathrm{mg}, \mathrm{T}=298 \mathrm{~K}, \mathrm{tc}=60 \mathrm{~min}$ ). equilibrium concentration, $\mathrm{Ce}$, at $298 \mathrm{~K}$. The effect of $\mathrm{pH}$ on the $\mathrm{Pb}^{2+}$ ions adsorption onto Corn cob was conducted in a $\mathrm{pH}$ range of $4-10$. The $\mathrm{pH}$ of solutions was adjusted by $0.1 \mathrm{M} \mathrm{HCl}$ or $0.1 \mathrm{M} \mathrm{NaOH}$ solutions. For every experiment, $100 \mathrm{ml}$ of the solution with $\mathrm{Pb}^{2+}$ concentration of $10 \mathrm{mg} . \mathrm{L}^{-1}$ was mixed with $50 \mathrm{mg}$ of Corn cob in a $250 \mathrm{ml}$ glass conical flask. The flask was shaken in a thermostatic orbit shaker at 220rpm for $60 \mathrm{~min}$. The mixed was filtered through a $0.45 \mu \mathrm{m}$ membrane filter. The filtrate was measured by atomic absorption then, the adsorption percentage (\%A) was determined as:

$$
\% A_{e}=\frac{A_{0}-A_{e}}{A_{0}} \times 100
$$

Where $\mathrm{Co}$ and $\mathrm{Ce}$ are the initial and final concentration of $\mathrm{Pb}^{2+i o n}$ in solution $\left(\mathrm{mg} \mathrm{L}^{-1}\right)$, respectively. qe, Amount adsorbed per unit weight of adsorbent at equilibrium ( $\left.\mathrm{mg} \mathrm{g}^{-1}\right)$ was calculated using the following equation:

$$
q_{e}=\frac{\left(C_{0}-C_{e}\right) V}{W}
$$

Where $\mathrm{mW}$ is the mass of Corn $\operatorname{cob}(\mathrm{g})$ and $\mathrm{V}$ is the volume of the solution (L). To evaluate the

Table 2: The effect of Corn cob dosage on the adsorption percentage (\%A) of $\mathrm{Pb}^{2+}\left(\mathrm{C}_{\mathrm{o}}=10 \mathrm{mg} \cdot \mathrm{L}^{-1}, \mathrm{pH}=6, \mathrm{~T}=298 \mathrm{~K}, \mathrm{tc}=60 \mathrm{~min}\right)$

\begin{tabular}{lcccccc}
\hline $\mathbf{W}_{\text {Corn cob }} / \mathbf{m g}$ & 10 & 20 & 30 & 40 & 50 & 60 \\
\hline$\% \mathrm{~A}$ & 45 & 51 & 58.2 & 63.1 & 81.5 & 81.5 \\
\hline
\end{tabular}

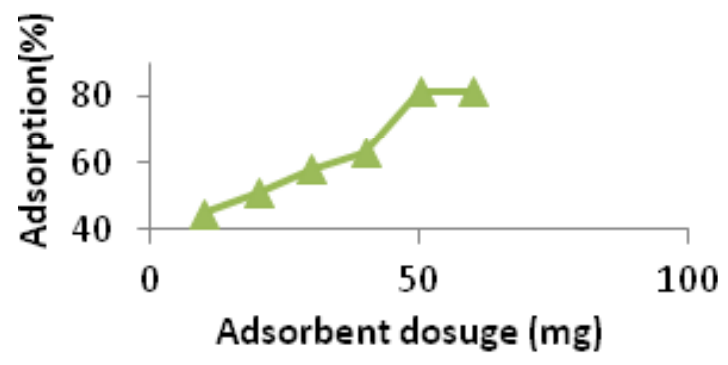

Fig. 4: The effect of Corn cob dosage on the adsorption percentage of lead ion onto Corn $\operatorname{cob}\left(\mathrm{C}_{\mathrm{o}}=10 \mathrm{mg} \cdot \mathrm{L}^{-1}, \mathrm{~T}=298 \mathrm{~K}, \mathrm{pH}=6, \mathrm{tc}=60 \mathrm{~min}\right)$

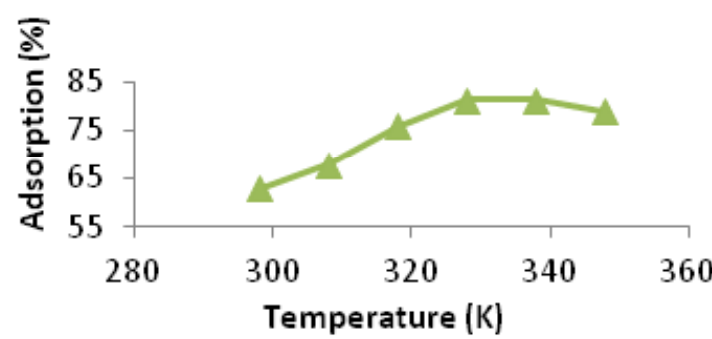

Fig. 5: The effect of temperature on the adsorption percentage of lead ion onto Corn $\operatorname{cob}\left(C_{0}=10 \mathrm{mg} \cdot \mathrm{L}^{-1}, \mathrm{~W}_{\text {Corn } \mathrm{cob}}=50 \mathrm{mg}, \mathrm{pH}=6, \mathrm{tc}=60\right.$ min) 
thermodynamic properties of the adsorption process, $50 \mathrm{mg}$ of Corn cob was added into the $100 \mathrm{ml}$ solution with $\mathrm{pH}$ of 6.0 and initial $\mathrm{Pb}^{2+}$ concentration ranging from $10 \mathrm{mg} \cdot \mathrm{L}^{-1}$ in every experiment. Each solution was shaken continuously for $60 \mathrm{~min}^{13-15}$.

\section{RESULTS AND DISCUSSTON}

\section{Adsorption study}

\section{Surface morphology}

Figures1 and 2 show the SEM images of Corn cobbefore and after adsorbents.Corn cob surface morphology before and after the absorption process in Figure 1 and 2 is shown. It is apparent porosity of the adsorbent and is the reason for the sinking of many metal ions absorbed by the absorbent biological. By comparing Figures 1 and 2 can be said that the difference created in the image

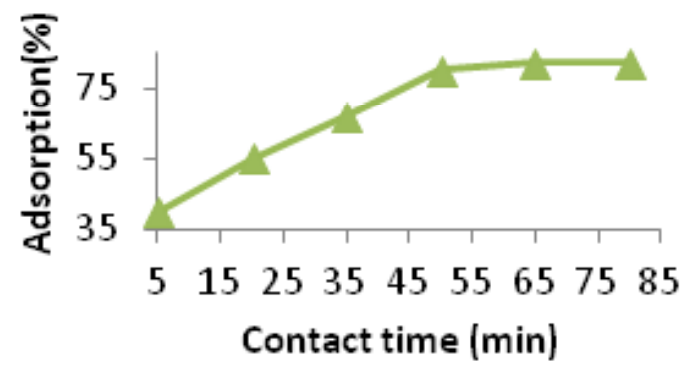

Fig. 6: The effect of contact time on the adsorption percentage of $\mathrm{Pb}^{2+}$ ion onto Corn $\operatorname{cob}\left(\mathrm{Co}=10 \mathrm{mg} \cdot \mathrm{L}^{-1}, \mathrm{~W}_{\text {Corn } \mathrm{cob}}=50 \mathrm{mg}, \mathrm{pH}=6, \mathrm{~T}=328\right.$ K) after the capture metal ions adsorbed on the surface SEM evidence is catchy.

\section{The effect of $\mathrm{pH}$}

Solution $\mathrm{pH}$ is one of the most important parameters to determine. The $\mathrm{pH}$ is one of most important environmental factor influencing not only site dissociation, but also the solution chemistry of the heavy metals. The $\mathrm{pH}$ value of the solution is an important controlling parameter in the adsorption process. ${ }^{16}$. Table 1 and fig. 3 illustrate the effect of the $\mathrm{pH}$ of the solution on the adsorption percentage of $\mathrm{Pb}^{2+}$ ion adsorbed onto Corn cob. The best results were obtained at $\mathrm{pH}=6$ for lead. The decrease of the adsorption percentage in acidic $\mathrm{pH}$ can be attributed to the repulsion between positive charge surface of Corn cob and $\mathrm{Pb}^{2+}$ Increase in metal removal with increase in $\mathrm{pH}$ can be explained on the basis of a decrease in competition between proton and metal cations for same functional groups and by decrease in positive surface charge, which results in a lower electrostatic repulsion between surface and metal ions. Decrease in adsorption at higher $\mathrm{pH}$ is due to formation of soluble hydroxyl complexes.

\section{The effect of Corn cob dosage}

The effect of Corn cob dosage on the adsorption percentage of $\mathrm{Pb}^{2+}$ ion are shown in table 2 and ploted in fig. 4. We concluded that the dosage of $50 \mathrm{mg}$ of Corn cob was the most suitable. After optimum dosage, all active sites are entirely exposed and the adsorption on the surface is saturated.

Table 3: The effect of temperature on the adsorption percentage $(\% A)$ of $\mathrm{Pb}^{2+}\left(\mathrm{C}_{\mathrm{o}}=10 \mathrm{mg} \cdot \mathrm{L}^{-1}, \mathrm{~W}_{\text {corn } \mathrm{cob}}=50 \mathrm{mg}, \mathrm{pH}=6, \mathrm{tc}=60 \mathrm{~min}\right)$

\begin{tabular}{lllllll}
\hline T / K & 298 & 308 & 318 & 328 & 338 & 348 \\
\hline$\% A$ & 63 & 68 & 76 & 81.4 & 81.4 & 79 \\
\hline
\end{tabular}

Table 4: The effect of contact time, tc, on the adsorption percentage $(\% A)$ of $\mathrm{Pb}^{2+}$ ions ( $\mathrm{Co}=10 \mathrm{mg} \cdot \mathrm{L}^{-1}, \mathrm{~W}_{\text {corn cob }}=50 \mathrm{mg}, \mathrm{pH}=6, \mathrm{~T}=328 \mathrm{~K}$ )

\begin{tabular}{lllllll}
\hline tc/min & 5 & 20 & 35 & 50 & 65 & 80 \\
\hline$\% A$ & 40 & 55 & 67 & 80 & 82 & 82 \\
\hline
\end{tabular}




\section{The effect of temperature}

Table 3 and fig. 5 show that the adsorption percentage decrease with increasing temperature. Therefore, it may be concluded that the interaction between $\mathrm{Pb}^{2+}$ ions and Corn cob is exothermic in nature. Adsorption decrease may be due to increase the electrostatic repulsion between of the $\mathrm{Pb}^{2+}$ ions.

\section{The effect of contact time}

The effect of contact time, tc, on the adsorption percentage of $\mathrm{Pb}^{2+}$ ion onto Corn cob are shown in table 4 and ploted in fig. 6 . A rather fast up take occurs during the first 50 min of the adsorption. It becomes slower as the adsorbed amount of $\mathrm{Pb}^{2+}$ ion reaches its equilibrium value. It can be seen that the adsorption process is rapid due to the availability of very active sites on the adsorbent surface at initial stage. This may be due to the special one atom layered structure of Corn $\operatorname{cob}^{17}$. At first adsorption capacity was a slow process then increases rapidly, it attains equilibrium and saturation gives constant adsorption value. The optimum contact time was obtained as $65 \mathrm{~min}$.

\section{Adsorption isotherm}

An adsorption isotherm is characterized by certain constant values, which express the surface properties of the adsorbent and so on the percentages adsorption of $\mathrm{Pb}^{2+}$ ion Corn cob as a function of initial concentration of $\mathrm{Pb}^{2+}$ ions are given in table 5 .

Equilibrium data of adsorption process can be analyzed on the basis of Freundlich and Langmuire models. The Freundlich equation is an empirical equation based on adsorption on a heterogeneous surface. The Freundlich isotherm equation is used for the description of monolayer (chemisorption) and multilayer (physisorption) adsorption ${ }^{18}$. The linearised form of Freundlich isotherm is given by the equation:

$$
\log q_{e}=\log P+\frac{1}{n} \log C_{e}
$$

Table 5: Adsorption data for $\mathrm{Pb}^{2+}$ adsorption onto corn cob ( $\mathrm{pH}=6, \mathrm{tc}=65 \mathrm{~min}, \mathrm{~T}=328 \mathrm{~K}, \mathrm{~W}_{\text {corn cob }}=50 \mathrm{mg}$ )

\begin{tabular}{lcccccc}
\hline Parameter & \multicolumn{7}{c}{ Value } \\
\hline $\mathrm{C}_{0} / \mathrm{mg} \mathrm{L}^{-1}$ & 2 & 4 & 6 & 8 & 10 & 12 \\
$\% \mathrm{~A}$ & 52 & 54.2 & 56.8 & 63.4 & 70.2 & 75.8 \\
$\mathrm{Ce} / \mathrm{mg} \mathrm{L}^{-1}$ & 0.96 & 1.832 & 2.6 & 2.93 & 2.98 & 2.904 \\
$\mathrm{q}_{\mathrm{e}} / \mathrm{mg} \mathrm{g}^{-1}$ & 2.08 & 4.336 & 6.8 & 10.14 & 14.04 & 18.192 \\
$\operatorname{log~Ce}$ & -0.018 & 0.263 & 0.41 & 0.47 & 0.5 & 0.46 \\
$\log \mathrm{q}_{\mathrm{e}}$ & 0.32 & 0.64 & 0.833 & 1.006 & 1.147 & 1.26 \\
$1 / \mathrm{Ce} / \mathrm{mg}^{-1}$ & 1.042 & 0.55 & 0.4 & 0.341 & 0.335 & 0.344 \\
$1 / \mathrm{q}_{\mathrm{e}} / \mathrm{g} \mathrm{mg}^{-1}$ & 0.481 & 0.291 & 0.15 & 0.1 & 0.07 & 0.05 \\
\hline
\end{tabular}

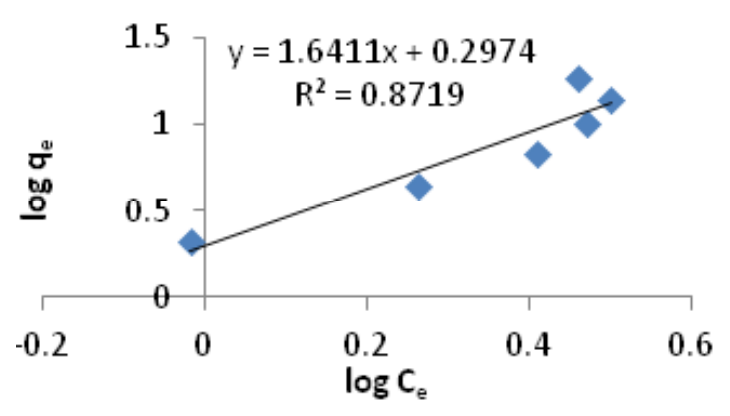

Fig. 7: Freundlich isotherm for lead ion adsorption onto corn cob

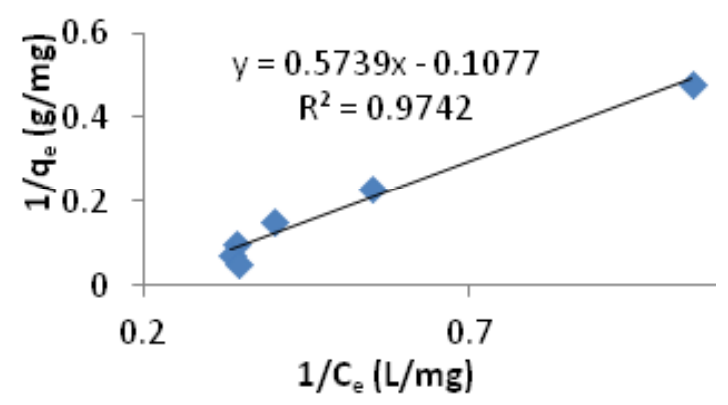

Fig. 8:Plot of (1/qe) versus (1/Ce) for $\mathrm{Pb}^{+2}$ adsorption onto corn cob 
Where $\mathrm{P}(\mathrm{L} / \mathrm{g})$ and $\mathrm{n}$ are the Emprical Freundlich constant or capacity factor and adsorption intensity ${ }^{19}$.

The Langmuire isotherm assumes monolayer adsorption on a homogeneous surface without any interaction between adsorbed ions and with uniform binding sites and equivalent sorption

Table 6: The resultant values for the studied isotherms in connection to $\mathrm{Pb}^{+2}$ ion adsorption onto corn cob at $298 \mathrm{~K}$

\begin{tabular}{ccc}
\hline Isotherm & Parameter & Value \\
\hline Freundlich & $\mathrm{P} /\left(\mathrm{L} \mathrm{g}^{-1}\right)$ & 2 \\
& $\mathrm{n}$ & 0.61 \\
& $\mathrm{R}^{2}$ & 0.8719 \\
Langmuire & $\mathrm{b} /\left(\mathrm{L} \mathrm{mg}^{-1}\right)$ & 0.2 \\
& $\mathrm{q}_{\mathrm{m}} /\left(\mathrm{mg} \mathrm{g}^{-1}\right)$ & 9.3 \\
& $\mathrm{R}^{2}$ & 0.9742 \\
\hline
\end{tabular}

energies ${ }^{20}$. The linearised Langmuir isotherm allows the calculation of adsorption capacities and Langmuir constant by the following equation:

$$
\frac{1}{q_{e}}=\frac{1}{b q_{m}}\left(\frac{1}{C_{e}}\right)+\frac{1}{q_{m}}
$$

Where $\mathrm{q}_{\mathrm{m}}\left(\mathrm{mgg}^{-1}\right)$ is the maximum metal ion to adsorb onto $1 \mathrm{~g}$ adsorbent and $\mathrm{b}(\mathrm{L} / \mathrm{mg})$ is the Langmuire constant related to adsorption capacity and energy of adsorption ${ }^{21}$.

The values of $\mathrm{K}_{\mathrm{F}}$ and $\mathrm{n}$ are determined from the intercept and slope of a plot of $\log q_{e}$ versus log Ce (table 5 and fig. 7) that were used to calculate the values of $P$ and $n$ (table 6)).

The slope and intercept of plot of $1 / q_{e}$ versus $1 / \mathrm{Ce}$ is shown in fig. 8 that were used to calculate the values of $b$ and $q_{m}$ (table 6).

Table 7: Separation factor for the adsorption of $\mathrm{Pb}^{2+}$ onto corn cob in terms of initial concentration of $\mathrm{Pb}^{2+}$

\begin{tabular}{lcccccc}
\hline Co / $\mathrm{mg} \mathrm{L}^{-1}$ & 2 & 4 & 6 & 8 & 10 & 12 \\
\hline $\mathrm{R}_{\mathrm{L}}$ & 0.71 & 0.6 & 0.5 & 0.4 & 0.33 & 0.3 \\
\hline
\end{tabular}

Table 8: The effect of temperature on Ko values (Co=10 mg. $\mathrm{L}^{-1}$, $\mathrm{pH}=6, \mathrm{~W}_{\text {Corn cob }}=50 \mathrm{mg}, \mathrm{tc}=65 \mathrm{~min}$ )

\begin{tabular}{lcccccc}
\hline $\mathrm{T} / \mathrm{K}$ & 298 & 308 & 318 & 328 & 338 & 348 \\
$\% \mathrm{~A}$ & 63 & 68 & 76 & 81.4 & 81.4 & 79 \\
$\mathrm{~K}_{0}$ & 1.7 & 2.13 & 3.17 & 4.38 & 4.38 & 3.96 \\
\hline
\end{tabular}

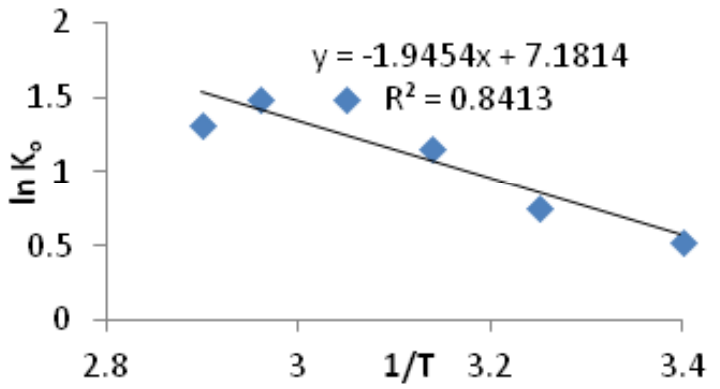

Fig. 9: The effect of temperature on equilibrium constant values
Table 9: Thermodynamic parameters for adsorption $\mathrm{Pb}^{+2}$ ions onto corn cob

\begin{tabular}{lccc}
\hline $\mathbf{T} / \mathbf{K}$ & $\Delta \mathbf{G} / \mathbf{k J m o l}{ }^{-1}$ & $\Delta \mathbf{H}^{\circ} / \mathbf{J m o l}^{-1}$ & $\Delta \mathbf{S}^{\circ} / \mathbf{J m o l}^{-1} \mathbf{K}^{-1}$ \\
\hline 298 & -1.31 & 16.2 & 59.71 \\
308 & -1.92 & 16.2 & 59.71 \\
318 & -3.04 & 16.2 & 59.71 \\
328 & -4.04 & 16.2 & 59.71 \\
338 & -4.16 & 16.2 & 59.71 \\
348 & -3.82 & 16.2 & 59.71 \\
\hline
\end{tabular}


The essential features of a Langmuir isotherm can be expressed in terms of a dimensionless constant separation factor or equilibrium parameter, $R_{L}$ that is used to predict if an adsorption system is favourable or unfavourable. The essential characteristic separation constant factor, $\mathrm{R}_{\mathrm{L}}$, for the Langmuire adsorption is defined as follows:

$$
R_{L}=\frac{1}{1+b C_{0}}
$$

The value of $R_{L}$ illustrate the shape of the isotherm to be either unfavorable $\left(R_{L}>1\right)$, linear $\left(R_{L}=1\right)$, favorable $\left(0<R_{L}<1\right)$ or irreversible $\left(R_{L}=0\right)$.

The calculated $R_{L}$ values versus initial $\mathrm{Pb}^{2+}$ concentration are given in table 7 , indicating that the Langmuire adsorption of $\mathrm{Pb}^{2+}$ onto Corn cob is favorable.

\section{Thermodynamic Parameters}

The thermodynamic parameters of adsorption process can be determined from the variation of thermodynamic equilibrium constant, $\mathrm{K}_{\mathrm{o}}^{22-24}$. Where $\mathrm{Ko}_{\mathrm{o}}$ is defined as follow:

$$
K_{0}=\frac{a_{S}}{a_{e}}=\frac{q_{e}}{C_{e}}=\frac{C_{0}-C_{e}}{C_{e}}
$$

Where $\mathrm{a}_{\mathrm{s}}$ and $\mathrm{a}_{\mathrm{e}}$ are the activity of adsorbed $\mathrm{Pb}^{2+}$ and the activity of $\mathrm{Pb}^{2+}$ in solution at equilibrium, respectively. The adsorption standard free energy change $\left(\Delta G^{0}\right)$ is calculated according to:

$$
\Delta \mathrm{G}^{0}=-\mathrm{RT} L n K_{0}
$$

The average standard enthalpy change $\left(\Delta \mathrm{H}^{\circ}\right)$ and the average standard entropy change $\left(\Delta S^{\circ}\right)$ are obtained from the plot of equation (8):

$\operatorname{Ln} K_{0}=\frac{\Delta S^{0}}{R}-\frac{\Delta H^{0}}{R T}$

In order to obtain the values of $\Delta \mathrm{H}^{\circ}$ and $\Delta \mathrm{S}^{\circ}$, was plotted InK against 1/T (table 8, fig. 9).

The obtained values of thermodynamic parameters $\left(\Delta \mathrm{G}^{0}, \Delta \mathrm{H}^{0}, \Delta \mathrm{S}^{0}\right)$ are listed in table 9 . The positive value of $\Delta \mathrm{H}^{0}$ suggests that the interaction of adsorbed $\mathrm{Pb}^{+2}$ with Corn cob is an endothermic process, which is supported by the decreasing the amount of lead ion adsorption with increasing temperature. The positive value of $\Delta S^{\circ}$ indicates a increased randomness and mobility at the adsorbent-solution interface during the adsorption of lead ion onto Corn cob. The negative values of $\Delta G^{0}$ reveals the fact that the adsorption process is spontaneous

\section{CONCLUSION}

The results of this work show that Corn $\mathrm{cob}$ is an effective adsorbent for removal of $\mathrm{Pb}^{2+}$ ion from aqueous solution. Results showed that the Langmuir isotherm model was fitted well with adsorption data, thus indicating the applicability of monolayer coverage of $\mathrm{Pb}^{2+}$ ion on Corn cob surface. Thermodynamic analysis showed that the adsorption process is endothermic and spontaneous in nature.

\section{REFERENCES}

1. Sun, S.; Wang, L.; Wang, A. Journal of Hazardous Materials. 2006, 136, 930-937.

2. Amarasinghe, B.M.W.P.K.; Williams, R.A. Chemical Engineering Journal. 2007,132, 299-309.

3. Goel, J.; Kadirvelu, K.; Rajagopal, C.; Garge, V.K. Journal of Hazardous Materials. 2005 125, 211-220.
4. Netzer, A.; Hughes, D.E. Water Research. 1984, 18, 927-933.

5. Kadirvelu, K.; kavipriya, M.; Karthika, C.; Radhika, M.; Vennilamani, N.; Pattabhi, S. Bioresour Technol. 2003, 87, 129-132.

6. Vijayaraghavan, K.; Winnie, H.Y.N.; Balasubramanian, R. Desalination. 2011, 266, 195-200. 
7. Abdul Halim, A.; Abdul Aziz, H.; Johari, M.A.M.; Ariffin, K.S. Desalination. 2010, 262, 31-35.

8. Kilic, M.; Apaydin-Varol, E.; Putun, A.E. Journal of Hazardous Materials. 2011, 189, 397-403.

9. Matos, J.; Nahas, C.; Rojas, L.; Rosales, M. Journal of Hazardous Materials. 2011, 196, 360-369.

10. Bazargan-Lari, R.; Bahrololoom, M.E.; Nemati, A. Journal of Food, Agriculture \& Environment. 2011, 9, 892-899.

11. Mozammel, H.M.; Masahiro, O.;Bahattacharya, S.C. Biomass and Bioenergy. 2010, 22, 397400.

12. George, Z.K. Journal of Hazardous Materials. 2012, 5, 1826-1840.

13. Demiral, H.; Demiral, I.; Karabacakoglu, B.; Tumsek, F. Chem. Eng. Res. Des. 2011, 89, 206-213.

14. Montes-Moran, M.A.; Suarez, D.; Menendez, J.A.; Fuente, E. J. Carbon. 2004, 42, 12191225.
15. Srinivasan, S.; Chelliah, P.; Srinivasan, V.; Stantley, A. B.; Subramani, K. Orient. J. Chem.2016, 32(1): 671-680.

16. Yimenez-Reyes, M.; Solache-Rios, M. J. Hazard, Mater. 2010, 180, 297-302.

17. Wu, Y.; Zhang, S.; Guo, X.; Huang, H. Technol. 2008, 99, 7709- 7715.

18. Yang, C.H. J. Colloid interface Sci. 1998, 208, 379-387.

19. Niwas, R.; Gupta, U.; Khan, A.A.; Vavshney, K.G. Colloids surf. 2000, A 164, 115-119.

20. Hutson, N.D.; Yang, R.T. Adsorption. 1997, 3, 189-195

21. Tan, C.Q.; Xiao, D. J. Hazard. Mater. 2009, 164, 1359- 1363.

22. Barkat, M.; Nibou, D.; Chearouche, P.; Mellah, A. Chem. Eng. Process. 2009, 48, 38-47.

23. Hashemian, S.; Parsaei, Y. Orient. J. Chem. 2015, 31(1), 177-184.

24. Mohammadkhani, S.; Gholami, M.R.; M. Aghaie. Orient. J. Chem. 2016, 32(1), 591599. 